\title{
MODULASI NEUROTRANSMITTER PADA GANGGUAN KOGNITIF HEWAN COBA DENGAN NANOEMULSI EKSTRAK IPOMOEA AQUATICA FORSK
}

\author{
Neurotransmitter Modulation In Disorders Animal Cognitive Test With Nanoemulsion \\ Ipomoea Aquatica Forsk Extract
}

\author{
Nadiatul Istiqamah Suaka ${ }^{\text {* }}$ \\ Salma Ersyara Putri Nugraha ${ }^{2}$ \\ Rizka Arum Pratiwi ${ }^{3}$ \\ Rahmadia Nurafifah ${ }^{4}$ \\ Endang Darmawan ${ }^{5}$
}

$*_{1,2,3,4,5}$ Fakultas Farmasi, Universitas Ahmad Dahlan, Kota Yogyakarta, Daerah Istimewa Yogyakarta, Indonesia

*email:

Endang.darmawan@pharm.uad.ac.id

Kata Kunci:

Ipomoea aquatica Forsk

Nanoemulsi

Neurotransmitter

\section{Keywords:}

Ipomoea aquatica Forsk

Nanoemulsion

Neurotransmitter

\begin{abstract}
Abstrak
Background. Alzheimer merupakan jenis demensia yang ditandai dengan terjadinya penurunan fungsi kognitif yang progresif, mencakup semua fungsi intelektual, sehingga menyebabkan seseorang mengalami kesulitan dalam melakukan aktivitas sehari-hari. Ipomoea aquatica forsk adalah tanaman yang memiliki kandungan antioksidan yang tinggi yang mampu meningkatkan perilaku kognitif, memori dan meningkatkan neurotransmitter.

Tujuan. Tujuan penelitian ini adalah untuk mengetahui efek modulasi neurotransmitter nanoemulsi ekstrak Ipomoea aquatica Forsk pada gangguan kognitif hewan coba.

Metode. Penelitian ini menggunakan 5 kelompok mencit yang terdiri kelompok kontrol normal, kelompok kontrol sakit, kelompok kontrol obat sebanyak dua tingkat dosis yaitu nanoemulsi ekstrak Ipomoea aquatica Forsk $200 \mathrm{mg} / \mathrm{kgBB}$ dan $400 \mathrm{mg} / \mathrm{kgBB}$ dan kelompok pembanding, masing masing kelompok terdiri dari 5 mencit. Seluruh kelompok diinduksi Trimethyltin (TMT) kecuali kelompok normal. Gambaran memori diperoleh dari uji morris water maze yang dianalisis dengan one-way repeated measure ANOVA.

Hasil. Nanoemulsi Ekstrak Ipomoea aquatica forsk dengan dosis $200 \mathrm{mg} / \mathrm{kgBB}$ mampu memperbaiki fungsi kognitif hewan coba yang ditandai dengan nilai hasil uji esktrak Ipomoea aquatica forsk menunjukkan hasil MWM yang hampir sama dengan mencit yang diberi donepezil.
\end{abstract}

\begin{abstract}
Backgrounds. Alzheimer's is a type of dementia characterized by a progressive decline in cognitive function, including all intellectual functions, causing a person to experience difficulties in carrying out daily activities. Ipomoea aquatica forsk is a plant that has a high antioxidant content that can improve cognitive behavior, memory and increase neurotransmitters.
\end{abstract}

Aim. The purpose of this study was to determine the modulating effect of the neurotransmitter nanoemulsion extract of Ipomoea aquatica Forsk on cognitive impairment in experimental animals.

Method. This study used 5 groups of mice consisting of a normal control group, a sick control group, a drug control group with two dose levels, namely nanoemulsion extract of Ipomoea aquatica Forsk $200 \mathrm{mg} / \mathrm{kgBW}$ and $400 \mathrm{mg} / \mathrm{kgBW}$ and a comparison group, each group consisted of 5 mice. All groups were induced by Trimethyltin (TMT) except the normal group. The memory image was obtained from the Morris Water Maze test which was analyzed by one-way repeated measure ANOVA.

Results. The Ipomoea aquatica forsk extract nanoemulsion with a dose of 200 $\mathrm{mg} / \mathrm{kgBW}$ was able to improve the cognitive function of experimental animals, which was indicated by the Ipomoea aquatica forsk extract test results showing almost the same MWM results as mice given donepezil.

\footnotetext{
(C) year The Authors. Published by Institute for Research and Community Services Universitas Muhammadiyah Palangkaraya. This is Open Access article under the CC-BY-SA License (http://creativecommons.org/licenses/bysa/4.0/). DOI: https://doi.org//0.33084/jsm.vxix.xxx.
} 


\section{PENDAHULUAN}

Kognitif merupakan salah satu fungsi tingkat tinggi otak manusia (Wibowo dan Karema, 2015). Fungsi kognitif sangat berpengaruh terhadap kehidupan seseorang baik secara sosial maupun secara psikis. Penurunan fungsi kognitif dapat menyebabkan seseorang mengalami kesulitan dalam melakukan aktivitas sehari-hari (Ramadian et al., 20/2). Gangguan fungsi otak pada tahap lanjut dapat menimbulkan penyakit tertentu seperti demensia (Alzheimer, gangguan vaskuler), jejas pada otak (traumatik dan stroke) dan gangguan kognitif lainnya (Asiah, 2013).

Alzheimer merupakan jenis demensia yang ditandai dengan terjadinya penurunan fungsi kognitif yang progresif, mencakup semua fungsi intelektual (Purba, 2020).

Patologi alzeimer yaitu adanya plak amyloid dan (NFT) yang mengakibatkan kematian neuron di otak terutama di area hippocampus. Kematian ini akan menyebabkan gangguan kognitif. Kematian neuron mengakibatkan acetylcholine (ACh) menuju cortex terganggu dan menyebabkan kematian neuron penghasil neurotransmiter ACh di nucleus basalis of Meynert (NBM) sehingga akan mengakibatkan gangguan memori. Acetylcholinesterase inhibitor dapat diberikan guna menghambat pemecahan $\mathrm{ACh}$ menjadi substitusi sementara (Purba, 2020).

Salah satu tanaman yang memiliki efek Acetylcholinesterase inhibitor yaitu Ipomoea aquatica forsk. Ipomoea aquatica Forsk memiliki aktivitas antioksidan yang tinggi. Ipomoea aquatica Forsk memiliki banyak kandungan nutrisi dan antioksidan seperti terpenoid, fenolik, flavonoid, alkaloid, poliol, asam organik, sterol dan asam amino (Rosli, 2019). Ipomoea aquatica Forsk memiliki aktivitas antioksidan yang tinggi karena mengandung tiga karotenoid; violaxanthin, lutein dan karoten (Fu et al., 20l I).

Ipomoea aquatica Forsk memiliki kemampuan untuk menghasilkan obat baru untuk pengobatan gangguan neurodegeneratif (Dhanasekaran et al., 20I5). Ipomoea aquatica Forsk mampu meningkatkan perilaku kognitif, memori dan meningkatkan neurotransmitter (Sivaraman et al., 2016). Ipomoea aquatica dalam ekstrak hidroalkolat memiliki aktivitas antikolinesterase yang signifikan (Dhanasekaran et al, 20I5). Ipomoea aquatica Forsk mampu menurunkan kadar AChE di otak dan memediasi gangguan kognitif dan memori (Sivaraman et al., 2016).

Aplikasi nanoteknologi untuk pangan dan obat-obatan menunjukkan kecenderungan yang terus meningkat. Teknologi ini menawarkan keunggulan dalam meningkatkan bioavailabilitas bahan aktif, pengendalian pelepasan bahan aktif serta memperbaiki sifat sensoris Jusnita dan Tridharma, 2019). Nanoemulsi dapat meningkatkan absorpsi, membantu melarutkan obat yang bersifat lipofilik, dan dapat meningkatkan bioavailabilitas obat yang berdampak pada meningkatnya absorbsi ekstrak Ipomoea aquatica Forsk pada saluran gastrointestinal yang mempengaruhi onset kerja ekstrak Ipomoea aquatica Forsk sebagai nutrisi otak (Sukmawati, 20II).

Demensia tipe Alzheimer pada hewan coba dapat diinduksi dengan Trimethyltin (TMT) karena TMT dapat menyebabkan gangguan proses memori dan menyebabkan kematian saraf pada otak hewan coba yaitu dengan mekanisme stres oksidatif. TMT menyebabkan penurunan fungsi kognitif dengan adanya neuro-degenerasi pada hipokampus (Yuliani \& Aspamufita, 2013).

Uji Morris Water Maze dapat menggambarkan memori pada hewan coba. Penelitian ini bertujuan untuk mengetahui efek modulasi neurotransmitter nanoemulsi ekstrak Ipomoea aquatica Forsk pada gangguan kognitif hewan coba.

\section{METODOLOGI}

\section{Alat dan Bahan}


Alat: ayakan 60 mesh, timbangan analitik, blender, kandang hewan, spuit injeksi I ml, spuit oral I ml, beaker glass, gelas ukur, pipet tetes, cawan poerselin, stopwatch, spektrofotometer, mikropipet, homogenizer, pipet ukur, pipet volume, oven, alat Soxhlet, rotary eveporator, waterbath, batang pengaduk, yellow tip, blue tip, tabung reaksi, kolam morris water maze, kamera video, handuk, dan hair dryer.

Bahan: Daun Ipomoea aquatica Forsk (kangkung air), Trimethyltin chloride (TMT), Aquades, Ethanol 96\%, Tween 80, Buffer Fosfat, Santan, Donepezil, dan $\mathrm{NaCl} 0,9 \%$.

\section{Metode pelaksanaan}

\section{Pembuatan Ekstrak Ipomoea aquatica Forsk}

Daun Ipomoea aquatica Forsk diperoleh dari Parangtritis KM.2I Yogyakarta sebanyak $10 \mathrm{~kg}$ dikumpulkan, dicuci dengan air mengalir, dikeringkan pada suhu ruangan selama 2 hari, kemudian dilanjut pengeringan menggunakan oven selama I-2 hari, selanjutnya daun kering diserbuk menggunakan blender, dan diperoleh serbuk simplisia Ipomoea aquatica Forsk sebanyak I kg.

Simplisia Daun Ipomoea aquatica Forsk kemudian diekstraksi menggunakan metode soxhletasi. Pelarut yang digunakan yaitu campuran aquadest:ethanol $96 \%$ (4:6). Ekstrak cair yang diperoleh kemudian dipekatkan menggunakan rotary evaporator pada suhu $70^{\circ} \mathrm{C}$ kemudian dipanaskan dengan waterbath guna menguapkan sisa-sisa pelarut dalam ekstrak sehingga diperoleh ekstrak kental.

\section{Pembuatan Nanoemulsi Ekstrak Ipomoea aquatica Forsk}

Ekstrak kental Ipomoea aquatica Forsk sebanyak 2 gram dilarutkan dalam $10 \mathrm{ml}$ etanol $96 \%$ (fase minyak). Larutan dicampurkan dengan Tween 80 dan dilarutkan dalam larutan buffer phospat PH 7 (fase air). Fase minyak dan fase air dicampur menggunakan homogenizer dengan kecepatan 30.000 rpm selama 20 menit.

\section{Formulasi Nanoemulsi Ekstrak Ipomoea aquatica Forsk}

Tabel I. Formula Nanoemulsi Ekstrak Ipomoea aquatica Forsk

\section{Persiapan Hewan Uji}

Hewan uji diaklimatisasi dengan kondisi laboratorium selama dua minggu, semua hewan ditempatkan di kandang menggunakan alas sekam kayu. Hewan diberi pakan pelet standar dan minum disediakan ad libitum.

\section{Perlakuan Terhadap Hewan Uji}

Hewan uji dibagi menjadi 5 kelompok secara acak, terdiri dari kelompok kontrol sehat, kontrol sakit, kontrol pembanding, dan kelompok uji sebanyak 2 tingkatan dosis. Pada hari ke I-7 setelah aklimatisasi, dilakukan pemberian buffer phospat ke kelompok I,

\begin{tabular}{|l|l|}
\hline Bahan & Formula \\
\hline etanol $96 \%$ & $20 \mathrm{ml}$ \\
\hline Tween 80 & $2 \mathrm{~g}$ \\
\hline Buffer fosfat & $78 \mathrm{ml}$ \\
\hline
\end{tabular}

$\mathrm{mg} / \mathrm{kgBB}$ ke kelompok 3, nanoemulsi ekstrak Ipomoea acuatica Forsk 400 mg/kgBB ke kelompok 4, dan donepezil $5 \mathrm{mg} / \mathrm{kgBB}$ ke kelompok 5 menggunakan spuit oral I $\mathrm{ml}$. Donepezil dibuat dengan cara dilarutkan kedalam $\mathrm{NaCl}$ 0,9\%. Kemudian di hari ke 8 mencit diinduksi Trimetiltin (TMT) dengan dosis II,2 $\mathrm{mg} / \mathrm{kgBB}$ secara intraperitoneal menggunakan spuit injeksi untuksemua kelompok (kecuali kontrol sehat). Kemudian dilanjutkan dengan pemberian perlakuan sesuaikelompoknya masing-masing selama 2I hari, dan pada hari ke-I5 sampai hari ke-2I dilakukan uji Moris Water Maze pada mencit.

\section{Uji Moris Water Maze}

Uji Morris Water Maze terdiri dari 3 tahapan yaitu acquisition trial, probe trial dan uji kemampuan sensorimotoris. Kolam dibagi menjadi empat kuadran secara imaginer. 
Acquisition trial dilakukan selama 5 hari. Mencit dilatih menemukan platform yang terletak $2 \mathrm{~cm}$ di bawah permukaan air pada salah satu kuadran sebanyak empat kali per hari. Mencit dimasukanpada salah satu kuadran secara random. Waktu diakhiri jika mencit telah mencapai platform atau setelah berenang selama 60 detik tetapi belum mencapai platform. Jika mencit tidak berhasil menemukan platform selama 60 detik maka mencit dibimbing untuk menemukanplatform dan ditempatkan di atas platform selama 15 detik sebelumlatihan berikutnya. Waktu dan jarak tempuh mencapai platform dicatat.

Probe trial, mencit dibiarkan berenang selama 60 detik tanpa platform. Kemudian dilakukan pencatatan terhadap waktu lamanya mencit berada di kuadran letak platform dan berapa kali mencit melintasi kuadran letak platform, hal ini juga dilakukan sebanyak empat kali tiap mencit.

Uji kemampuan sensori-motoris platform terletak 2 cm di bawah air yang sudah diberi santan. Letak platform diubah-ubah pada kuadran yang berbeda tiap latihan. Mencit dimasukan pada salah satu kuadran kecuali pada kuadran yang ditempati platform. Tiap mencit dilatih empat kali, jika selama 60 detik mencit tidak dapat mencapai platform maka mencit akan dibimbing untuk menemukan platform. Waktu mencit menemukan platform dicatat (Safwan et al., 20l4).

\section{Analisis Data Uji Moris Water Maze}

Hasil dicatat sebagai waktu latensi dan jarak pada acquisition trial, berapa kali dan berapa lama waktu mencit berada dikuadran platform pada probe trial, dan normal atau tidaknya aktivitas sensorimotoris. Data kemudian dianalisis secara statistik, uji normalitas dilakukan dengan menggunakan uji KolmogorovSmirnov (jika data lebih lebih dari 50) atau uji SaphiroWilk (jika data kurang dari 50) dan uji homogenitas dilakukan dengan uji Levene. Data waktu latensi dan panjang lintasan ditransformasi menjadi data $\log 10$ sehingga data terdistribusi normal dan homogen kemudian dianalisis statistik dengan one way repeated measure ANOVA dan dilanjutkan dengan uji posthoc Tukey HSD. Data hasil uji probe trial dan sensorimotor, jika data terdistribusi normal dan homogen diuji dengan one way ANOVA dilanjutkan dengan uji posthoc Tukey HSD.

\section{HASIL DAN PEMBAHASAN}

\section{Ekstrak Ipomoea aquatica forsk}

Metode ekstraksi Ipomoea aquatica forsk yang digunakan adalah soxhletasi. Dasar pemilihan metode ini karena pada metode soxhletasi serbuk simplisia disari oleh cairan penyari yang murni sehingga dapat menyari zat aktif lebih banyak.

Ekstrak kental Ipomoea aquatica forsk diperoleh sebanyak 10 gram. Karakteristik ekstrak kental Ipomoea aquatica forsk hasil ekstraksi yaitu berwarna hijau kecoklatan, kental, dan berbau khas.

\section{Nanoemulsi Ekstrak Ipomoea aquatica Forsk}

Nanoemulsi Ekstrak Ipomoea aquatica forsk yang diformulasikan termasuk kedalam kategori emulsi minyak dalam air. Fase terdispersi yaitu fase minyak (campuran ekstrak Ipomoea aquatica forsk dan etanol 96\%) dan fase pendispersi yaitu fase air (buffer phospat $\mathrm{pH} 7)$.

Hasil sediaan nanoemulsi ekstrak Ipomoea aqutica forsk yang diperoleh memiliki karakteristik cair, berwarna hijau tua, dan berbau khas.

\section{Efek TMT pada hewan coba}

Trimetiltin digunakan untuk menginduksi terjadinya demensia model alzheimer. Trimetiltin diberikan pada hari ke 8 setelah pemberian perlakuan pada masing masing kelompok hewan uji, tujuannya adalah agar hewan uji mendapat zat aktif dari sediaan nanoemulsi ekstrak Ipomoea aquatica forsk dan ataupun donepezil di dalam darah sebelum dipaparkan TMT. Paparan TMT dapat menyebabkan disorentasi, agresif, dan kejang kejang pada hewan uji. Berdasarkan hasil pengamatan mencit yang diinduksi TMT mengalami 
penurunan berat badan, tingkah lakunya lebih agresif, bulu-bulunya menjadi mudah rontok dan kusam.

\section{Hasil Uji Morris Water Maze}

Tabel I. Uji Aquisition Trial Hari ke-2

\begin{tabular}{|c|c|c|c|c|c|}
\hline No & Kelompok & $\begin{array}{l}\text { Panjang } \\
\text { Lintasan }\end{array}$ & $P$ value & $\begin{array}{l}\text { Waktu } \\
\text { Latensi }\end{array}$ & $\begin{array}{l}P \\
\text { value }\end{array}$ \\
\hline I. & Normal & $\begin{array}{l}0,526 \pm \\
0,119\end{array}$ & 0,012 & $\begin{array}{l}I, 311 \pm \\
0,074\end{array}$ & 0,010 \\
\hline 2. & TMT & $\begin{array}{l}0,668 \pm \\
0,172\end{array}$ & - & $\begin{array}{l}, 548 \pm \\
0,079\end{array}$ & - \\
\hline 3. & $\begin{array}{l}\text { TMT + } \\
\text { NE } 200 \\
\mathrm{mg} / \mathrm{kgBB}\end{array}$ & $\begin{array}{l}0,206 \pm \\
0,102\end{array}$ & 0,001 & $\begin{array}{l}1,074 \pm \\
0,104\end{array}$ & 0,001 \\
\hline 4. & $\begin{array}{l}\text { TMT + } \\
\mathrm{NE} 400 \\
\mathrm{mg} / \mathrm{kgBB}\end{array}$ & $\begin{array}{l}0,496 \pm \\
0,106\end{array}$ & 0,024 & $\begin{array}{l}1,428 \pm \\
0,160\end{array}$ & 0,359 \\
\hline 5. & $\begin{array}{l}\text { TMT + } \\
\text { Donepezil }\end{array}$ & $\begin{array}{l}0,426 \pm \\
0,099\end{array}$ & 0,002 & $\begin{array}{l}1,384 \pm \\
0,041\end{array}$ & 0,115 \\
\hline
\end{tabular}

Tabel II. Uji Aquisition Trial Hari ke-3

\begin{tabular}{|c|c|c|c|c|c|}
\hline No & Kelompok & $\begin{array}{l}\text { Panjang } \\
\text { Lintasan }\end{array}$ & $P$ value & $\begin{array}{l}\text { Waktu } \\
\text { Latensi }\end{array}$ & $\begin{array}{l}\mathrm{P} \\
\text { value }\end{array}$ \\
\hline 1. & Normal & $\begin{array}{l}0,412 \pm \\
0,134\end{array}$ & 0,012 & $\begin{array}{l}I, 29 I \pm \\
0,204\end{array}$ & 0,015 \\
\hline 2. & TMT & $\begin{array}{l}0,662 \pm \\
0,119\end{array}$ & - & $\begin{array}{l}1,612 \pm \\
0,130\end{array}$ & - \\
\hline 3. & $\begin{array}{l}\text { TMT + } \\
\text { NE } 200 \\
\mathrm{mg} / \mathrm{kgBB}\end{array}$ & $\begin{array}{l}0,254 \pm \\
0,045\end{array}$ & 0,001 & $\begin{array}{l}1,102 \pm \\
0,131\end{array}$ & 0,001 \\
\hline 4. & $\begin{array}{l}\text { TMT + } \\
\text { NE } 400 \\
\mathrm{mg} / \mathrm{kgBB}\end{array}$ & $\begin{array}{l}0,506 \pm \\
0,143\end{array}$ & 0,192 & $\begin{array}{l}1,370 \pm \\
0,134\end{array}$ & 0,090 \\
\hline 5. & $\begin{array}{l}\text { TMT + } \\
\text { Donepezil }\end{array}$ & $\begin{array}{l}0,362 \pm \\
0,055\end{array}$ & 0,002 & $\begin{array}{l}1,318 \pm \\
0,082\end{array}$ & 0,028 \\
\hline
\end{tabular}

Tabel III. Uji Aquisition Trial Hari ke-4

\begin{tabular}{|l|l|l|l|l|l|}
\hline No & Kelompok & $\begin{array}{l}\text { Panjang } \\
\text { Lintasan }\end{array}$ & P value & $\begin{array}{l}\text { Waktu } \\
\text { Latensi }\end{array}$ & $\begin{array}{l}\text { value } \\
\text { val }\end{array}$ \\
\hline I. & Normal & $\begin{array}{l}0,462 \pm \\
0,086\end{array}$ & 0,015 & $\begin{array}{l}\mathrm{I}, 239 \pm \\
0,777\end{array}$ & $0,00 \mathrm{I}$ \\
\hline 2. & TMT & $0,602 \pm$ & - & $\mathrm{I}, 540 \pm$ & - \\
& & 0,104 & & 0,033 & \\
\hline
\end{tabular}

\begin{tabular}{|c|c|c|c|c|c|}
\hline 3. & $\begin{array}{l}\text { TMT + } \\
\text { NE } 200 \\
\text { mg/kgBB }\end{array}$ & $\begin{array}{l}0,108 \pm \\
0,036\end{array}$ & $0,00 \mathrm{I}$ & $\begin{array}{l}1,019 \pm \\
0,106\end{array}$ & $0,00 \mathrm{I}$ \\
\hline 4. & $\begin{array}{l}\text { TMT + } \\
\text { NE } 400 \\
\mathrm{mg} / \mathrm{kgBB}\end{array}$ & $\begin{array}{l}0,438 \pm \\
0,101\end{array}$ & 0,072 & $\begin{array}{l}1,209 \pm \\
0,130\end{array}$ & $0,00 \mathrm{I}$ \\
\hline 5. & $\begin{array}{l}\text { TMT + } \\
\text { Donepezil }\end{array}$ & $\begin{array}{l}0,406 \pm \\
0,111\end{array}$ & 0,023 & $\begin{array}{l}1,358 \pm \\
0,102\end{array}$ & 0,050 \\
\hline
\end{tabular}

Tabel III. Uji Aquisition Trial Hari ke-5

\begin{tabular}{|c|c|c|c|c|c|}
\hline No & Kelompok & $\begin{array}{l}\text { Panjang } \\
\text { Lintasan }\end{array}$ & $\begin{array}{l}P \\
\text { value }\end{array}$ & $\begin{array}{l}\text { Waktu } \\
\text { Latensi }\end{array}$ & $\begin{array}{l}P \\
\text { value }\end{array}$ \\
\hline $\mathrm{I}$. & Normal & $\begin{array}{l}0,474 \pm \\
0,164\end{array}$ & 0,013 & $\begin{array}{l}1,313 \\
\pm \\
0,221\end{array}$ & 0,003 \\
\hline 2. & TMT & $\begin{array}{l}0,730 \pm \\
0,056\end{array}$ & - & $\begin{array}{l}1,675 \\
\pm \\
0,08 \mathrm{I}\end{array}$ & - \\
\hline 3. & $\begin{array}{l}\text { TMT + NE } \\
200 \\
\mathrm{mg} / \mathrm{kgBB}\end{array}$ & $\begin{array}{l}0,108 \pm \\
0,069\end{array}$ & 0,001 & $\begin{array}{l}0,912 \\
\pm \\
0,074\end{array}$ & 0,001 \\
\hline 4. & $\begin{array}{l}\text { TMT + NE } \\
400 \\
\mathrm{mg} / \mathrm{kgBB}\end{array}$ & $\begin{array}{l}0,432 \pm \\
0,151\end{array}$ & 0,003 & $\begin{array}{l}1,434 \\
\pm \\
0,152\end{array}$ & 0,065 \\
\hline 5. & $\begin{array}{l}\text { TMT + } \\
\text { Donepezil }\end{array}$ & $\begin{array}{l}0,500 \pm \\
0,651\end{array}$ & 0,029 & $\begin{array}{l}I, 36 I \\
\pm \\
0,063\end{array}$ & 0,010 \\
\hline
\end{tabular}

Data waktu panjang lintasan dan waktu latensi menunjukan data yang homogen dan terdistribusi normal. Hasil uji menunjukkan bahwa data terdistribusi normal dan homogen (sig > 0,05) sehingga kemudian dilakukan uji one way ANOVA. Hasil uji one way ANOVA menunjukkan nilai sig < 0,05 dari hari ke 2 hingga hari ke 4 sehingga memberi kesimpulan bahwa ada kelompok-kelompok yang berbeda signifikan. Analisis selanjutnya menggunakan uji posthoc Tukey HSD. Kemudian dilakukan perbandingan antar kelompok perlakuan dengan kelompok sakit (TMT). Dari hari ke 2 hingga hari ke 4 terdapat perbedaan bermakna $(P$ value $(s i g)<0,05)$ antara kelompok sakit dan seluruh kelompok 
perlakuan kecuali kelompok uji Nanoemulsi 400 $\mathrm{mg} / \mathrm{kgBB}$.

\section{Probe Trial}

Tabel IV. Uji Probe Trial

\begin{tabular}{|c|c|c|c|c|c|}
\hline $\mathrm{N}$ & $\begin{array}{l}\text { Kelomp } \\
\text { ok }\end{array}$ & $\begin{array}{l}\text { Frekuen } \\
\text { si } \\
\text { Berada } \\
\text { di } \\
\text { Kuadra } \\
\text { n } \\
\text { Target }\end{array}$ & $\begin{array}{l}P \\
\text { valu } \\
\text { e }\end{array}$ & $\begin{array}{l}\text { Presenta } \\
\text { se (\%) } \\
\text { Lama } \\
\text { Waktu } \\
\text { di } \\
\text { Kuadran } \\
\text { Target }\end{array}$ & $\begin{array}{l}P \\
\text { valu } \\
\mathrm{e}\end{array}$ \\
\hline I. & Normal & $\begin{array}{l}4,00 \pm \\
1,225\end{array}$ & $\begin{array}{l}0,04 \\
4\end{array}$ & $\begin{array}{l}0,267 \pm \\
0,057\end{array}$ & $\begin{array}{l}0,03 \\
9\end{array}$ \\
\hline 2. & TMT & $\begin{array}{l}I, 60 \pm \\
0,894\end{array}$ & - & $\begin{array}{l}0,139 \pm \\
0,038\end{array}$ & - \\
\hline 3. & $\begin{array}{l}\text { TMT + } \\
\text { NE } 200 \\
\text { mg/kgBB }\end{array}$ & $\begin{array}{l}4,80 \pm \\
I, 304\end{array}$ & $\begin{array}{l}0,00 \\
5\end{array}$ & $\begin{array}{l}0,270 \pm \\
0,106\end{array}$ & $\begin{array}{l}0,03 \\
4\end{array}$ \\
\hline 4. & $\begin{array}{l}\text { TMT + } \\
\text { NE } 400 \\
\mathrm{mg} / \mathrm{kgBB}\end{array}$ & $\begin{array}{l}3,00 \pm \\
0,707\end{array}$ & $\begin{array}{l}0,4 I \\
0\end{array}$ & $\begin{array}{l}0,256 \pm \\
0,056\end{array}$ & $\begin{array}{l}0,06 \\
7\end{array}$ \\
\hline 5. & $\begin{array}{l}\text { TMT + } \\
\text { Donepe } \\
\text { zil }\end{array}$ & $\begin{array}{l}4,20 \pm \\
1,789\end{array}$ & $\begin{array}{l}0,02 \\
6\end{array}$ & $\begin{array}{l}0,276 \pm \\
0,044\end{array}$ & $\begin{array}{l}0,02 \\
4\end{array}$ \\
\hline
\end{tabular}

Data frekuensi mencit berada di kuadran target dan presentase lama waktu dan kuadran target uji menunjukan data yang homogen dan terdistribusi normal (sig > 0,05) sehingga kemudian dilakukan uji one way ANOVA. Hasil uji one way ANOVA menunjukkan nilai sig $<0,05$ sehingga memberi kesimpulan bahwa ada kelompok-kelompok yang berbeda signifikan. Analisis selanjutnya menggunakan uji posthoc Tukey HSD. Kemudian dilakukan perbandingan antar kelompok perlakuan dengan kelompok sakit (TMT). Antara kelompok sakit dan seluruh kelompok perlakuan kecuali kelompok uji Nanoemulsi $400 \mathrm{mg} / \mathrm{kgBB}$ terdapat perbedaan bermakna (sig <0,05).

\section{Sensori Motoris}

Tabel V. Uji Kemampuan Sensori Motoris

\begin{tabular}{|c|c|c|c|}
\hline No & Kelompok & $\begin{array}{l}\text { Sensori } \\
\text { Motoris }\end{array}$ & $P$ value \\
\hline $\mathrm{I}$. & Normal & $\begin{array}{l}1,335 \pm \\
0,301\end{array}$ & 0,906 \\
\hline 2. & TMT & $\begin{array}{l}1,441 \pm \\
0,117\end{array}$ & - \\
\hline 3. & $\begin{array}{l}\text { TMT + NE } 200 \\
\mathrm{mg} / \mathrm{kgBB}\end{array}$ & $\begin{array}{l}1,234 \pm \\
0,215\end{array}$ & 0,464 \\
\hline 4. & $\begin{array}{l}\text { TMT + NE } 400 \\
\mathrm{mg} / \mathrm{kgBB}\end{array}$ & $\begin{array}{l}1,410 \pm \\
0,158\end{array}$ & 0,999 \\
\hline 5. & TMT + Donepezil & $\begin{array}{l}1,297 \pm \\
0,103\end{array}$ & 0,763 \\
\hline
\end{tabular}

Data hasil uji sensorimotor menunjukkan bahwa data terdistribusi normal dan homogen (sig > 0,05). Analisis selanjutnya menggunakan uji one way ANOVA. Hasil uji one way ANOVA menunjukan nilai sig > 0,05. Hal ini menunjukkan bahwa tidak ada perbedaan yang signifikan sensori motoris di antar kelompok, sehingga kemampuan memori tikus tidak disebabkan karena adanya gangguan sensori, motor dan motivasi dari hewan uji.

Salah satu tanda terjadinya alzeimer yaitu mengingkatnya aktivitas asetil kolinesterase (AChE), enzim ini bertanggung jawab untuk menghindrolisis asetilkolin, baik dari neuron kolinergik maupun non kolinergik (Dhanasekaran et al., 20I5). Meningkatnya enzim AChE menyebabkan penurunan asetilkolin terutama di daerah hipocampus yang menjadi area melakukan tugas memori utama sehingga hal ini menyebabkan penurunan fungsi neurotransmitter pada penderita alzeimer. Asetilkolin sendiri memainkan peran sentral dalam transmisi saraf dasar, konsentrasi, memori dan pembelajaran (Sivaraman \& Muralidaran, 2010).

Studi menunjukkan bahwa nanoemulsi Ekstrak Ipomoea aquatica forsk dengan dosis $200 \mathrm{mg} / \mathrm{kgBB}$ mampu memperbaiki fungsi kognitif hewan coba yang ditandai dengan nilai hasil uji esktrak Ipomoea aquatica forsk menunjukkan hasil MWM yang hampir sama dengan mencit yang diberi donepezil. 
Nanoemulsi ekstrak Ipomoea aquatica Forsk mampu menghambat AChE sehingga kandungan Ach di hipokampus semakin meningkat dan berefek pada peningkatan fungsi kognitif hewan coba. Hal ini dapat disebabkan karena aktivitas antioksidan dari nanoemulsi ekstrak Ipomoea aquatica Forsk yang berperan sebagai antikolinesterase. Antioksidan dapat meredam radikal bebas pada hewan coba yang diinduksi TMT.

\section{KESIMPULAN}

Berdasarkan hasil penelitian dapat disumpulkan bahwa Nanoemulsi ekstrak Ipomoea aquatica Forsk dapat memodulasi neurotransmitter Ach pada mencit

\section{UCAPAN TERIMA KASIH}

Terimakasih kepada kementerian Pendidikan,

Kebudayaan, Riset dan Teknologi yang telah mendanai penelitian ini.

Terimakasih kepada Universitas Ahmad Dahlan yang telah memfasilitasi penelitian ini.

\section{REFERENSI}

I. Wibowo, M. M., dan Karema, W. 2015. Gambaran Fungsi Kognitif Dengan INA-MoCA dan MMSE Pada Penderita Post-Stroke di Poliklinik Saraf BLU RSUP Kandou Manado November-Desember 20I4. Jurnal e-CliniC. 3 (3):754-757.

2. Ramadian, D., Maja, J., dan Runtuwene T. 2012. Gambaran Fungsi Kognitif pada Lansia di Tiga Yayasan Manula di Kecamatan Kawangkoan. Universitas Sam Ratulangi. Manado.

3. Asiah, N. 20/3. Air dan Gangguan Fungsi Kognitif. Majalah Kesehatan Pharmamedika. 5 (I).

4. Purba, I. S. 2020. Inflamasi dalam Patologi Penyakit Alzheimer. Medicinus, 33 (3):65-7I.

5. Rosli, N. H. S. B. M. 2019. Antioxidant and anticholinesterase activities of Ipomoea aquatica Forssk. And Ipomoea reptans Poir. Disertasi.
Faculty of Science University of Malaya, Kuala Lumpur.

6. Fu, H., Xie, B., Ma, S., Zhu, X., Fan, G., dan Pan, S. 20II. Evaluation of antioxidant activities of principal carotenoids available in water spinach (Ipomoea aquatica). Journal of Food Composition and Analysis. 24 (2):288-297.

7. Dhanasekaran, S., Perumal, P., dan Palayan, M. 2015. In-vitro Screening for acetylcholinesterase enzyme inhibition potential and antioxidant activity of extracts of Ipomoea aquatica Forsk: therapeutic lead for Alzheimer's disease. lournal of Applied Pharmaceutical Science. 5 (02):012-016.

8. Sivaraman, D., Panneerselvam, P., dan Muralidharan, P. 2016. Memory and Brain Neurotransmitter Restoring Potential of Hydroalcoholic Extract of Ipomoea aquatica Forsk on Amyloid Beta A beta (25-35) Induced Cognitive Deficits in Alzheimer's Mice. International Journal of Pharmacology. 12 (2):52-65.

9. Jusnita, N., dan Tridharma, W. S. 2019. Karakterisasi nanoemulsi ekstrak daun kelor (Moringa oleifera Lamk.). Jurnal Sains Farmasi dan Klinis. 6 (I): 16-24.

10. Sukmawati, D. D. 20II. Formulasi Mikroemulsi Ekstrak Herba Pegagan (Centella asiatica L Urb) dengan Variasi Kadar Tween 80. Skripsi. Fakultas Matematika dan Ilmu Pengetahuan Alam Universitas Islam Indonesia, Yogyakarta.

II. Yuliani, S. 2016. Efek Ekstrak Rimpang Kunyit (Curcuma Longa Linn) Terstandar Kurkumin Pada Tikus Model Demensia Yang Diinduksi Trimetiltin. Disertasi. Universitas Gadjah Mada.

12. Aspamufita, N., \& Yuliani, S. (20I3). Efek ekstrak etanol rimpang temulawak (curcuma xanthorrhiza roxb) terhadap memori spasial tikus model demensia yang diinduksi trimethyltin. Pharmaciana, 3(2). 